\title{
Avatars of Eurocentrism in the Critique of the Liberal Peace ${ }^{1}$
}

\author{
Meera Sabaratnam, University of Cambridge
}

\begin{abstract}
Recent scholarly critiques of the so-called 'liberal peace' raise important political and ethical challenges to practices of post-war intervention in the global South. However, their conceptual and analytic approaches have tended to reproduce rather than challenge the intellectual Eurocentrism underpinning the liberal peace. Eurocentric features of the critiques include the methodological bypassing of target subjects in research, the analytic bypassing of subjects through frameworks of governmentality, the assumed ontological split between the 'liberal' and 'local' and a nostalgia for the liberal subject and liberal social contract as alternative bases for politics. These collectively produce a 'paradox of liberalism' which sees liberal peace as oppressive but also the only true source of emancipation. However, a re-politicisation of colonial difference offers an alternative 'decolonising' approach to critical analysis through repositioning the analytic gaze. Three alternative research strategies for critical analysis are briefly developed.
\end{abstract}

Keywords: liberal peace, Eurocentrism, governmentality, culture, colonial difference

Like the god Vishnu, Eurocentrism has many avatars (Wallerstein 1997). These allow it to come into being age after age, to meet different adversaries and set its followers back on its own path. For those who recognise Eurocentrism as a problem within the study of world politics and wish to overcome it, it is necessary to be perpetually reflexive about its recurrent and evolving manifestations. This has been a major preoccupation of postcolonial security studies and international relations (Barkawi and Laffey 2006; Jones 2006; Shilliam 2010; Hobson 2012).

This issue has also been in the sights of many critical accounts of the liberal peace, which interrogate the security-development nexus and its prescriptions for intervention (e.g. Duffield 2001, 2007, Chandler 2006, Richmond 2005, Pugh 2004, 2005; Mac Ginty 2011). ii Overall the liberal peace can be understood as a set of particular ideas and practices intended to reform and regulate polities in the Global South so as to avoid both poverty and conflict. In contrast to the reassuring tenor of

\footnotetext{
${ }^{1}$ Particular thanks are due to Devon Curtis, John Heathershaw, Mark Hoffman, Paul Kirby and David Rampton for insightful comments during the preparation of the article, as well as to the Editors and reviewers.
} 
'policy-relevant' conflict management and statebuilding strategies, the critical literature has fundamentally called into question the political significance and legitimacy of the liberal peace as a form of imperial global order

In Duffield's words:

...liberal peace embodies a new or political humanitarianism that lays emphasis on such things as conflict resolution and prevention, reconstructing social networks, strengthening civil and representative institutions, promoting the rule of law, and security sector reform in the context of a functioning market economy. In many respects, while contested and far from assured, liberal peace reflects a radical developmental agenda of social transformation. In this case however, this is an international responsibility and not that of an independent or single juridical state. (Duffield, 2001: 10-11)

These critiques have been suspicious of policies that project liberal peacebuilding strategies as merely effective technical solutions to the linked problems of violent conflict, underdevelopment and state weakness (Götze and Guzina, 2008, Chandler 2010a). Rather, the critiques elaborate insightful accounts of the politics of international interventions in 'post-conflict' or 'fragile' environments.

These critiques are 'anti-imperial' in orientation and ethic; that is to say that they derive much of their intellectual significance from exposing the tensions between norms and ethics of self-determination, democracy and sovereignty, and the neo-imperial interventionist discourses and practices that constitute the liberal peace (Chandler 2006; Zaum 2007). They respond to a much larger 'mainstream' literature on peacebuilding which has broadly sought to defend its core practices, (e.g. Paris, 2010; Ignatieff 2003; Caplan 2005; see also discussion by Cunliffe 2012). The common charge within the critiques of 'neocolonialism' or 'imperialism' is thus understood as being serious as it implies association with an illegitimate relation of rule.

However, despite growing interest in the 'everyday', 'local' or 'subaltern' actors in post-conflict societies and their modes of 'resistance' or 'hybridity' (Richmond 2011, Mac Ginty 2011), the critiques have failed to address systematically the deeper problems of 'Eurocentrism' in how we think and research the politics of the international. As Walker (1993) has argued, IR theory is itself political theory; that is to say that it circumscribes our understanding of the 'possible' in world politics through its ontologies and epistemologies. This insight however must also be applied to our traditions of critical theory.

The core contribution of this article is an interrogation of the Eurocentric limits of thought in the critical liberal peace literature, which close down rather than 
open up counter-hegemonic modes of thinking the international (see also Krishna 1993, Hobson 2007, 2012). Thus, although the critical literature's ethics are often 'post-colonial', the analytics can be further 'decolonised'. In this sense, the push in this article to 'decolonise' critiques of the liberal peace can be seen as sympathetic to the anti-imperial ethos of the existing literature, if critical of its limits. Getting beyond those limits requires a deep appraisal of the particular forms of Eurocentrism in social theory. Such an appraisal leads towards a repoliticization of assumptions of 'difference'.

This article begins by identifying three major variants of Eurocentrism at work in social theory. It then unpacks key features of critical accounts of the liberal peace and discusses the ways in which they are inhabited by avatars of Eurocentrism. These culminate in what we might call a 'paradox of liberalism'. Finally it offers three strategies for 'decolonising' research on the developmentsecurity nexus through a re-positioning of the analytic gaze.

\section{What is Eurocentrism and why does it matter?}

Although Eurocentrism has multiple incarnations, overall, it can be described as the sensibility that Europe is historically, economically, culturally and politically distinctive in ways which significantly determine the overall character of world politics. As a starting point, we might regard it as a conceptual and philosophical framework that informs the construction of knowledge about the social world - a foundational epistemology of Western distinctiveness. In this sensibility, 'Europe' is a culturalgeographic sphere (Bhambra 2010: 5), which can be understood as the genealogical foundation of 'the West'. In his piece 'Eurocentrism and Its Avatars', Immanuel Wallerstein (1997) argues that many critical literatures in world history nonetheless reproduce tropes of Eurocentrism in their analyses. In this article I argue similarly, focusing on the critiques of the liberal peace in IR and IPE. Here I suggest these avatars can be grouped under three broad headings: culturalist, historical and epistemic.

Some of Eurocentrism's culturalist avatars, as identified by Wallerstein (1997), are now relatively well-recognised by scholars across various disciplines. The most famous is probably Orientalism, which is a framing of the East through negative and/or feminised stereotypes of its culture, political character, social norms and economic agency. This framing casts it as a space of tradition and opportunity to be governed and explored, or alternatively feared, by the rational and enlightened West (Said 1973). This is closed allied to the avatar of civilisational thinking which assigns to the West as a whole a package of secular-rational, Judeo-Christian, liberal democratic tolerant social values, in contrast to other civilisations such as the 'Indic' 
(Wallerstein 1997: 97-98). However, this culturalist avatar seems to have taken new forms since the apparent decline of public Orientalism. As Balibar (1991) has suggested, there are important functional continuities between old and new frameworks based on 'civilisation', 'race' and 'cultural difference' in reproducing an idea of Western distinctiveness. Although now rarely supremacist, this culturalist form of Eurocentrism is generative: it posits the core ontological difference between the West and its others as deriving from their distinctive cultures or civilisations, with major political issues emerging from the question of cultural difference and how to manage this.

Eurocentrism is also manifested through historical avatars. The first of these is the assumption that Europe is the principal subject of World History, as discussed by the Subaltern Studies research group, and especially Chakrabarty (2000). This is the tendency of historians (Hobsbawm is offered as the exemplar) to see the emergence of capitalism and industrialisation in the West as the real driver of History, and non-Western societies as either 'outside history' or as lagging behind Western historical development. A closely related historical avatar includes the notion of Historical Progress (Wallerstein 1997: 96), as elaborated in much postHegelian theory, which understands human history as not just linear but selfconsciously improving the human condition through the trying out of different political ideas. Again, these particular forms are understood as somewhat outmoded in scholarship, although they seem to reappear in new guises.

More recent critiques for example point to the attribution of the West with historical 'hyper-agency' in terms of world-historical development (Hobson 2006, 2007, 2012), even if few scholars maintain a strictly Hegelian story of historical Progress. For Bhambra (2010), the emphasis is on the assumption of 'endogeneity' in the story of the rise of Europe - the idea that European development was selfgenerating - driven by war, competition, the Enlightenment and technological advances - and then diffused out to the rest of the world via imperial expansion. This thus re-instates Europe as the implicit subject of world history and historical sociology, and occludes the contemporaneous and necessary involvement of the wider world in this rise (see also Barkawi and Laffey 2006). Both old and new historical versions of Eurocentrism understand different parts of the world as more and less 'developed', or more and less 'modern', indicating a strong connection between geographic-cultural space and temporal/scalar positioning (see also Hindess 2007; Hutchings 2008b).

Finally, we can identify Eurocentrism's epistemic avatar, which is the purported a-temporal universalism of modern social scientific knowledge (Wallerstein 1997: 100). In this tendency, social scientific modes of knowledge which emerged in Europe from the $19^{\text {th }}$ century onwards are represented as supremely 
privileged in their understanding of social phenomena above other modes of knowing, as demonstrated through their powers of abstraction, reasoning and objectivity. This also establishes a hierarchy of knowers with the authority to speak about the world, which tracks their positions in relation to the Western academy.

A newer school of thought on these questions has argued for re-politicising of this epistemic Eurocentrism through recognising the fundamental co-constitution of 'modernity' and 'coloniality' in the contemporary production of knowledge about world politics (Mignolo 2000, 2002; Quijano 2000, 2007). Thus, even the apparently 'postmodern' critiques of social science do not disrupt the overall claims to hegemony of social-scientific or legal knowledge. (Mignolo 2002: 86-90). This knowledge presents itself as a logically bounded totality. Relatedly, there is a systematic blindness to and erasure of what is exterior to the colonial-modern enterprise, and its associated knowledges.

This exteriority is produced and reinforced through the structural colonial hierarchies of dispossession and entitlement that continue to characterise 'postcolonial' global relations, which reproduce 'colonial difference'. A key issue here is that 'colonial difference' as lived is fundamentally to do with power and positionality rather than a foundational framework of culture or historical exceptionalism. Thus, even critiques of the exploitative character of the global system can reinforce the primacy of the colonial-modern standpoint of knowledge. For Mignolo and Quijano, a de-colonial or decolonising project is one which draws attention to the limiting character of colonial and Eurocentric epistemologies, and seeks to recover other sites for re-grounding the analytic gaze.

Overall, the sustenance of these different Eurocentric avatars matters because it circumscribes our understanding of what is politically possible; to follow Walker's line of argument, it creates the conceptual terrain upon which our reflections take place. In some instances, quite clearly it leads to a general belief in and legitimisation of Western primacy, but does not always translate into a support for imperialism (Hobson 2012). The important thing is that its imaginary is shaped by the asserted 'fact' of a basic and unbridgeable cultural-historical divide between the West and its others. As will be discussed, this can lead to a circumscribed sense of the possibilities for connections and solidarities between the West and non-West, as well as a limited articulation of what an anti-imperial politics can look like.

These accounts of the complex and multi-layered character of intellectual Eurocentrism set stiff challenges for researchers who are engaged in trying to rethink the international. Specifically, they set the challenge of engaging critically with particular structures of power and knowledge without simultaneously reifying and naturalising Western distinctiveness. This task is particularly urgent for scholars 
thinking about the 'liberal peace' - the character, effects and legitimacy of intervention in post-colonial societies by formerly colonising powers. Without a substantive alternative to the Eurocentric philosophical terrain upon which the debates have taken place, the critiques themselves may become 'apologia' (Chandler 2010b: 137) for what exists rather than grounds for alternative political practices. Thus whilst much of the work that has emerged is extremely valuable and illuminating - it is also often 'inadequate', to borrow Chakrabarty's term (2000).

What follows is a reading of the critical debates on the liberal peace which argues that avatars of Eurocentrism are fundamental to many of the critical narratives. Not all avatars in the liberal peace critiques are manifested in all cases; indeed, some of the conceptual differences between them can be read as conflicts between different modes of Eurocentric thought. Different thinkers' practices vary at different times. And none of these accounts are 'crudely' Eurocentric in the sense of being anachronistically Orientalist or triumphalist. Rather their analyses are often informed by 'cutting' edge critical theory. Moreover, with some authors there is a growing awareness of the problems thrown up by their own frameworks, resulting in some attempts to address them through new thinking. However, overall this has so far not resulted in any substantive attempt to grapple with the deeper philosophical assumption of Western distinctiveness behind critical narratives themselves, nor to recognise its recurring manifestations.

\section{Avatars of Eurocentrism in critical thought}

The critical debate on the liberal peace is haunted by four particular avatars of Eurocentrism, which extend from the categories above: a methodological bypassing of target subjects in empirical research; the analytic bypassing of subjects in frameworks of governmentality; an ontology of cultural Otherness via the 'liberal'/'local' divide; and critical nostalgia for the liberal social contract, a liberal subject and European social democracy. These collectively constitute a 'paradox of liberalism' in which Western liberalism is seen as a source of oppression but also implicitly understood as the only true source of emancipation. This section and the next elaborate these issues in more depth, whilst the final section of the article outlines paths for 'decolonising' the analytic gaze in the critique of liberal peace developed from different traditions of critique.

\section{Methodological bypassing of target subjects in research}

Whilst this cannot be said to be the trend in much of the more recent research on the liberal peace, in the earlier work which set the research agenda, and in later formulations, there was a tendency to exclude or marginalise consideration of the 
people targeted by its interventions from the analysis. This methodological exclusion manifested itself in different ways.

In a seemingly banal sense, it was often manifested in work which sought to focus principally on the conceptualisation of the liberal peace rather than its specific effects. Thus, some major works in the debate such as Richmond's Transformation of Peace (2005) and Chandler's International Statebuilding: The Rise of Post-Liberal Governance (2010) did not represent or engage with the activities or behaviour of particular peoples targeted by interventions since these were not considered relevant to the overall framing of this part of the research. Rather, such projects focused on making sense of the genealogies, contradictions and trajectories of intellectual traditions associated with the 'West' as the key object of intellectual concern. In the context of these deliberations, the peoples targeted by intervention were implicitly irrelevant to the conclusions that the research wanted to draw about the West's relationship with post-conflict environments. Whilst this is a methodological 'exclusion', then, it does not on the surface appear a problematic one - rather, it seems a natural artefact of a research design focused on Western ideology.

Contributing to the theoretical framing, methodological exclusion of targeted peoples also characterised some of the empirical work on particular interventions. This often focused very largely on the policies, beliefs and practices of interveners. Exemplary of this were Chandler's Faking Democracy After Dayton (2000) and Empire In Denial (2006), which almost exclusively looked at the international administrative structures and their illiberal and hypocritical exercise of power. Where Bosnians did appear it was briefly and through a short explanation of their nationalist politics in the context of anti-corruption policies (2006: 154-7).

This same methodological exclusion is however also manifested in other influential writings. For example, in the cases covered in Richmond and Franks' Liberal Peace Transitions (2009), the focus is almost exclusively on the trajectory of the interventions. References to Kosovans, Cambodians and Timorese people are relatively brief, generally about recalcitrant politicians and offered in service of a critique that demonstrates the failure of the liberal peace to transform societies. Chesterman (2008) argues that the same applies to Zaum's (2007) treatment of target societies. Even in Duffield's work, which has included substantial efforts to ground the global theoretical critique in particular cases, the overarching tendency is to focus on the interveners and their practices in those environments rather than the peoples targeted by intervention. We see this particularly accentuated in the handling of the Zambezia Road Feeder Project in Mozambique (2007: 82-110) and continuities in Western attitudes towards Afghanistan (133-158). Again, there is a seemingly solid rationale for this - that this is the right methodological choice to make because these interventions are themselves the object of inquiry. 
Yet, it is a fundamental of most philosophies of social science that methodological choices reflect underlying ontological premises (Jackson 2010). As noted, our ontological premises determine our basic understanding of what the political is (Walker 1993). In these cases, to look only at interveners, and to imply by design that this is an adequate account of the politics of intervention helps to reproduce, however unintentionally, the background assumption that that which is exterior to this does not matter for an appreciation of the politics of intervention. The fact that no explicit methodological rationale is usually offered for this absence suggests further that this is a matter of scholarly common sense.

Thus defining and framing inquiry in this way supports habits of intellectual Eurocentrism by emphasising 'Western' agency as the terrain of the political. What is under question then is not whether the methods used were adequate to the research question, but why research questions about the politics of the liberal peace have been continuously framed in this way. On our reading, this methodological habit precisely reproduces tenets of 'old' Eurocentrism here - the implied passivity, irrelevance or mysteriousness of the non-West - even as it tries to avoid them. It will be argued that in combination with other avatars of Eurocentrism, it has played an important role in the construction of the 'paradox of liberalism' within the debate.

Analytic bypassing of subjects through governmentality frameworks

Allied to the methodological exclusion of peoples targeted by interventions is a deeper analytic bypassing of such peoples as substantive political subjects, via critical accounts of global governance. Specifically, the recent critical debate on the liberal peace has also been strongly influenced by the idea that it is a form of liberal governmentality (Dillon and Reid 2000). This is the idea, derived from Foucault, that it is a productive technology of power which seeks to regulate life through its freedom - through the production of self-governing liberal subjects. This is understood to operate through a system of biopolitics (Duffield 2005, Richmond 2006), which articulates sovereign power as shifting from a management of territories to a management of bodies. This debate has been unfolding alongside the broader rise of Foucaultian analytics of the international, and particular in analyses of war, peace and global governance (Jabri 2007; Joseph 2010).

This analytic framework, particularly as developed by Duffield in the two books cited here $(2001,2007)$, has been incredibly powerful as a critical imaginary for understanding the structure and practices of the development-security nexus and liberal peace. Whilst the first book details the emerging strategic complex of actors humanitarian, military, developmental - who intervene widely in the Global South 
in new configurations, the second articulates these practices via a Foucaultian reading of liberal power and the expanding frontier of Western governance.

Duffield offers his reading of liberal peace, through Foucault, as a contrast to theses suggesting that interventions are a 'new imperialism' (2001: 31-34). Rather, liberal power is 'based on the regulation and management of economic, political and social processes' (34). One of the most important themes emerging from the later work $(2005,2007)$ is the unevenness of life-chances and developmental expectations accorded to the liberal West and the rest of the world. For Duffield this is a continuation of colonial strategies of rule (2005) and liberal racism (2007: 185-214) we might also call it the production of 'colonial difference' in Mignolo's terms. Duffield roots this analysis in Harvey's critique of capitalism's tendency and need to reproduce 'surplus populations' to avoid systemic crises (2007: 10-11).

However, the central problem with this analytic framework is its tendency to ignore the exteriority of power through the discounting of Southern subjecthood. It does this in different ways. This turns on the way in which political power and political subjecthood are implicitly understood to interact and produce consent:

People in the South are no longer ordered what to do - they are now expected to do it willingly themselves. Compared to imperial peace, power in this form, while just as real and disruptive, is more nuanced, opaque and complex. Partnership and participation imply the mutual acceptance of shared normative standards and frameworks. Degrees of agreement, or apparent agreement, within such normative frameworks establish lines of inclusion and exclusion. (Duffield 2001: 34)

Here it is strongly implied that liberal governmentality in the international sphere operates in the way liberal governmentality operates within 'advanced liberal societies' (Joseph 2010); that is specifically through the productive power of liberal discourse to produce self-regulating and self-governing subjects. If it is the case that the liberal peace consists of a strategic complexes of governance consisting of different actors (Duffield 2001: 12), then the implication is that they are governing the global South through the production of liberal subjectivity.

Nonetheless, the way Duffield frames it here actually hedges the bet over Southern subjectivity whilst simultaneously endorsing the overall framework. That is, he does not want to say outright that Southern political subjecthood is produced by the liberal peace. Yet, this is the point of the 'governmentality' framework insofar as it has any analytic traction, i.e. that it is a specific modality of power which works through the production of volition rather than coercion or loyalty. Throughout the work then, we have a fairly strong narrative of the liberal peace and development- 
security network as a web or network of Western liberal power, the logic of which works through its attempted production of liberal subjects.

There are long-standing debates as to whether a Foucauldian account of power is applicable at a global level (Joseph 2010), adequate for understanding either the development of governmental structures themselves, or for understanding the nature and character of 'resistance'. As Jabri (2007: 74) notes, postcolonial critiques have argued that Foucault's own focus on the European expression of power ignores the differentiated character of imperial power. In particular, they have problematized Foucault's ignoring of the specific historical angle or positionality that informs his account of power (Jabri 2007, 74), and subsequently his account of resistance that is itself ideologically somewhat empty, as noted by Spivak (Jabri 2007, 75).

These concerns can be applied to the use of his work in the liberal peace debate, and are specifically connected to the account of the subject that is implicit in the governmentality framework. Chandler has made similar claims, arguing that there is an emptiness to Duffield's call for a 'solidarity of the governed' as a response to governmentality (Chandler 2009: 67), because it lacks a political subject as the basis for critical theorising (2010b: 153)

Chandler is right to an extent; there is a lack of political subjecthood in Duffield's account of intervention. However, what he does not clearly specify is that the principal lack is of the subjecthood of those targeted by intervention, not those seen to be enacting it. The latter actually have plenty of strategic agency, intentionality, ideology and purpose in this framework. In this sense, Duffield's account of intervention is not dissimilar to Chandler's, in that they both focus on the agency and subjecthood of interveners, even if under the analytic of governmentality this becomes more diffuse. Yet they both exclude and avoid considerations of the exteriority of this power, and particularly the peoples targeted by interventions as political subjects. The habit of methodological exclusion noted in the previous section becomes then cognate with the analytic exclusions which underpin the framework of governmentality. Both exhibit avatars of Eurocentrism, which emphasise the distinctiveness and importance of Western behaviour whilst occluding the space outside it.

\section{Ontologies of Otherness: liberal-local relations, 'hybridity', 'resistance' and the 'everyday'}

Sensitive to the problem of such occlusion, a major strand of recent literature has emphasised the need to re-think the relations between the 'liberal' and the 'local' in intervention settings (Mac Ginty 2011, Richmond 2009, 2010, 2011), in what has 
been labelled a 'fourth-generation' approach (Richmond 2011). This writing has taken a much more pro-active approach to research with and about the peoples targeted by intervention, aiming to correct the impression of smooth liberal transformation and the 'romanticisation' of the local (Mac Ginty 2011: 2-4). Yet the paths it has taken have, quite unwillingly, reinforced a Eurocentric understanding of intervention, through using an ontology of 'Otherness' to frame the issues.

Prominent amongst these accounts is Richmond's recent work on 'post-liberal peace' $(2009,2010,2011)$, which frames the key problems of intervention through an ontological distinction between the 'liberal' and the 'local'. In earlier writing, the liberal peace is elaborated as genealogically endogenous to Western traditions of thought, reflecting Enlightenment, modern and post-Christian values (Richmond 2005). In post-conflict-settings however it is critiqued for exercising forms of hegemony that suppress pluralism, depoliticise peace, undermine the liberal social contract and exercise a colonial gaze in its treatment of local 'recipients' of the liberal peace. In view of these various aspects of failure, the liberal peace is characterised as 'ethically bankrupt' (2009a: 558) and requiring re-evaluation.

The 'local' on the other hand is a space characterised by 'context, custom, tradition and difference in its everyday setting' (2010: 669), which is suppressed by liberal peace interventions. The very conception of the 'post-liberal peace' is thus about the ways in which two ontologically distinct elements - the 'liberal' and 'local' are 'rescued and reunited' via forms of hybridity and empathy, in which 'everyday local agencies, rights, needs, custom and kinship are recognised as discursive 'webs of meaning' (2010: 668).'

Mitchell has recently argued that Richmond's conception of the 'local' is not 'a reference to parochial, spatially, culturally or politically bounded places' but 'the potentialities of local agents to contest, reshape or resist within a local "space" (Mitchell, 2011: 1628). Richmond himself has also been concerned not to be understood as 'essentialising' the 'local', emphasising that it contains a diversity of forms of political society (2011: 13-14). Indeed, in this more recent work, a more complex conception of the 'everyday' as a space of action, thought and potential resistance is elaborated.

Despite these qualifications, however, there is much conflation, interchangeability and slippage between these conceptions of the 'local'. Accordingly, the ontology of Otherness, understood as cultural distinctiveness and alterity, continuously surfaces throughout the narratives of liberal and post-liberal peace. Not only is the liberal peace closely linked to the intellectual trajectory of the 'West', but a conception of the 'local' as non-modern and non-Western often reappears: 
This requires that local academies and policymakers beyond the already liberal international community are enabled to develop theoretical approaches to understanding their own predicaments and situations, without these being tainted by Western, liberal, and developed world orthodoxies and interests. In other words, to gain an understanding of the 'indigenous' and everyday factors for the overall project of building peace, liberal or otherwise, a via media needs to be developed between emergent local knowledge and the orthodoxy of international prescriptions and assumptions about peace. (Richmond 2009: 571, emphasis added)

There is a clear emphasis here on the need to engage with the 'indigenous' or 'authentic' traditions of non-Western life, which seems to reflects an underlying assumption of cultural difference as the primary division between these two parties. This reproduces the division between the liberal, rational, modern West and a culturally distinct space of the 'local'.

Indeed, the call for a post-liberal peace is often a call for peacebuilding to reflect a more "culturally appropriate form of politics" (2011: 102) which is more empathetic and emancipatory. This emphasis on tradition and cultural norms as constitutive of the 'local' is carried through in recent research on interventions in Timor Leste and the Solomon Islands. These focus largely on the reinvigoration of 'customary' houses and institutions as a form of 'critical agency' in distinction to liberal institutions and the state (2011: 159-182). The point here is not simply that there is an account of alterity or cultural difference within the politics of intervention, but that the liberal/local distinction appears to be the central ontological fulcrum upon which the rest of the political and ethical problems sit (see also Chandler 2010b: 153). Therefore 'local' or 'everyday' 'agency' is seen to be best expressed to the extent that it reclaims 'the customary' and is not 'co-opted' by the internationals. It is understood as enhanced where codes of 'customary law' becomes part of the new constitutional settlement.

A similar division can be seen Mac Ginty's framework, which sees the hybridities in peacebuilding as emerging at the intersection of the 'international' and 'local' agents and institutions (2011). Again, this framework is built on an ontological distinction between the two which repeatedly splits the 'Western'/'international' from the 'non-Western'/'local'. Even though this is well-qualified, overall Mac Ginty defends this distinction, arguing that if one were to abandon such potentially problematic labels then this would lead to an abandonment of research altogether (2011: 94). This can quite straightforwardly be read as a defence of the basic ontology of the project, which is an ontology of the distinction between the West and its Others, which meet through various forms of hybridisation. Whilst Mac Ginty does 
not pursue the ethics of the post-liberal peace in the same way as Richmond, the underlying intellectual framework also uses this distinction as the analytic pivot of the research.

We earlier defined Eurocentrism as the belief in Western distinctiveness, and I have argued that this is philosophically fundamental to this strand of the critical literature which grapples with the relationship between the 'liberal' and 'local'. This strand has put substantial analytic weight on fundamental cultural differences between these two entities, even whilst disavowing any essentialism and making some substantive conceptual efforts to move away from this. Such difficulties are indicative of the deep hold that this particular avatar of Eurocentrism has on the critical imaginary. By contrast, the point made by a wide variety of other 'postcolonial' writers has precisely been against such an ontology of the international, pointing instead to the historically blurred, intertwined and mutually constituted character of global historical space and 'culture' (Bhabha 2004; Bhambra 2010).

Nostalgia for social contract politics, welfare democracy and the liberal political subject

The three avatars just discussed are prominent features of critiques which shape the basic starting points of research. This last avatar can however be characterised as more 'recessive' in critical scripts, occupying a more muted but important place in the overall thinking. This is an implicit nostalgia for the social contract, the liberal subject and the welfare state, which are understood to provide the substance of alternatives to the present liberal peace. However, as will be further elaborated, these end up reinforcing the rationale for interventions rather than disrupting them.

The 'social contract' or even 'liberal social contract' are sometimes invoked in the critiques as a means of restoring balance between powerful and less powerful actors, but also as a way of shoring up the liberal peace itself through moving away from neoliberalism. For Richmond, a 'new social contract' offers a means of balancing of the international with the indigenous, which provides the basis for a post-liberal peace with more 'everyday legitimacy' (2009: 567-8). For Divjak and Pugh, writing in the context of corruption in post-conflict Bosnia, the main cause of corruption is understood as the 'absence of a liberal social contract' (2008: 373). This resonates with other literature that has pointed to the 'external' rather than 'internal' contract engendered by peacebuilding (Barnett and Zürcher 2009).

This line of argument is interesting precisely because of the strong suggestion that what is required is not a rejection of intervention, but the need to control it by bringing it into a classical liberal framework of accountability through contract. If 
only such contractarian relations were available to guide international-local relations, or indeed the relations between elites and masses, then the liberal peace could, in Richmond's words, be 'salvaged'. Practitioners might of course point out that in a formal sense there are plenty of 'contracts' and agreements that govern intervention in all peacebuilding missions - governments necessarily consent to them, and constitutions are also forged through political processes which are designed to be 'inclusive'. For critics who know this, however, the implication must be that these are not genuine or authentic forms of contracting.

Complementary to the call for a (better) social contract is also a call for more welfare provision and state intervention in post-conflict economies (Pugh 2005, 2009; Richmond 2008) within a critique of neoliberal economic policy. This resonates with Duffield's observation that the provision of 'social insurance' for 'surplus populations' in the global North is not replicated in the South (2007: 217). In particular, Pugh emphasises the need for employment creation and labour rights (2008), and Richmond emphasises the meeting of basic needs and rights through better state provision (2008). These stipulations are both however combined with an emphasis on the need to uphold 'culture' or 'heterogeneity' (Pugh et al 2008) in the context of a developmental political economy, and with a consciousness of the problems of some of these objectives (Richmond 2011: 39).

Whilst the critique of the effects of neoliberal economic policy in these writings is very insightful and important, it is nonetheless interesting that the alternative vision is clearly based on a particular conception of state-led social democracy akin to that practiced in post-war Western Europe, but one which is able to accommodate culturally-appropriate modifications and development. Again, however, practitioners might well point to this as actually reflecting the current centre of gravity in intervention policy ("we are all Keynesian now", quoted in Richmond 2011: 169). Moreover, they may note that it is Western donors themselves that have enabled any kind of social provision via health and education services to take place. Whilst critics might argue soundly that such provisions are everywhere inadequate, this does not seem to reflect any kind of real gap in thinking between interveners and critics.

In a slightly different vein, other critiques have shown a nostalgia for the liberal political subject as a basis of political action. Earlier, for example, we noted that Chandler (2010b) critiqued Duffield for the thinness of the idea of the 'solidarity of the governed'. In the same piece, Richmond is also criticised for a fear of doing epistemic violence to 'the Other'. These concerns reflect Chandler's criticisms of post-structuralist and cosmopolitan approaches, which mourn the loss of the 'liberal right-bearing subject' (2009: 56) and the 'transformative dynamic ontology of the universal rational subject' (2010b: 155). 
This is because, for Chandler, liberal peace does not represent so much the contradictions of divergent strands of liberalism but a degraded 'neoliberal' form which critiques autonomy (2010b). Whilst it is never made totally explicit what kind of politics of engagement Chandler would advocate, it is clear that his preoccupations with autonomy, sovereignty and the virtual death of political ideologies in the West indicate a kind of re-founded pluralist liberalism in which 'politics' and 'autonomy' are themselves more highly valued as the foundation of a properly political project. Yet as Jones has recently argued, this seems to depend upon an implicit defence of the 'mythology' (Chandler's word) of unproblematic autonomy as the basis for political society (Jones 2011: 237). Indeed, the focus on the unaccountability of intervention and the critique of autonomy suggests that he too might be in favour of a classical liberal social contract as the alternative to neoliberalism.

Thus the critiques of the liberal peace often remain tied to alternatives which reflect political imaginaries grounded in the vision of a 'better' European past, either in terms of ideas about the social contract or welfare state, or about the autonomous liberal political subject. These imaginaries may all be improvements in many respects on the present situation; however, it is perhaps disconcerting that these alternatives are framed in terms of and with references to such a past, and that there is little real difference between these visions and those that practitioners of intervention themselves hold. As will be argued in the next section, these are an important limit to the potentiality of critique through confining the intellectual spaces from which critique can emerge.

\section{Framing Intervention through the Paradox of Liberalism}

In a recent piece defending liberal peacebuilding, Roland Paris accuses its critics of failing to come up with alternatives to it, arguing that mostly they endorse variants of liberalism, or just nothing at all (2010: 354-7; see also Begby and Burgess 2009). Indeed, in terms of the defence he offers, this is one of the most biting countercritiques: There Is No Alternative. He is partially right, but, I will argue, for the wrong reasons. The problems emerge not because there is nothing ultimately better than liberalism, but because the deeper framework of philosophical Eurocentrism denies the possibility of any real political exteriority to this broad category of ideas. Thus for Paris it becomes relatively easy to claim that anything short of self-declared and non-consensual totalitarian colonialism enforced through naked violence is actually some form of - implicitly acceptable - 'liberalism', because there is an intellectual conflation of 'Western' activity with liberal action. 
This leaves critiques trapped in a 'paradox of liberalism', which on the one hand problematizes its biopolitics, cultural inappropriateness, neoliberal economic policies and unaccountability, but on the other responds to these problems through either some kind of middle ground or some kind of 'proper' liberalism of the past. This is the circle in which interventions and its critics find themselves enclosed, with interventions themselves apparently softening their edges and filling the space through emphases on 'local ownership', 'participatory governance', multidimensional approaches to poverty reduction and political 'partnership' with aid-recipient countries.

These reforms in intervention practice accordingly often overlap with critiques to such an extent that it is unclear whether critiques themselves have only become descriptive, rather than critical, of the present directions in intervention policy. Overall, Duffield is consistently more conscious and sceptical of these colonial dimensions of the present security-development nexus (2005), and of the longer entanglements of 'liberal' intervention practices with racism, imperialism and attempts to control the colonial frontier (2007). Others seem to recognise these continuities; yet both Mac Ginty and Richmond cite the creation of the Tribal Liaison Council in Afghanistan as an indication of 'hybridity' between the international and local, and the emergence of the 'post-liberal peace'. But is this really something to be celebrated as more 'culturally appropriate', or does it rather represent a more efficient instrument of neo-colonial governance?

Hutchings (2008a) has argued that whilst 'masculinity' and 'war' are both unstable categories, they are nonetheless mutually constitutive because they render each other intelligible as categories of social practice. A similar relationship can be understood to exist between the intellectual frameworks of Eurocentrism and the liberal peace. This means that the liberal peace itself only makes sense when the philosophical frames of Eurocentrism - i.e. Western distinctiveness - have already been accepted. Conversely, it also means that practices such as those of the liberal peace continue to reinvigorate the basic tenets of intellectual Eurocentrism.

Subsequently, it is because we are so used to thinking of the world through Eurocentric perspectives that anything truly different to the liberal peace as a response to conflict, poverty and political crisis becomes itself unthinkable - we see this through the calls of the critics for the liberal peace to become either more liberal or more culturally appropriate. However, we also see it in the most systemic of the critiques - that of Duffield, for whom few alternatives are seriously forwarded other than a fairly empty Foucaultian solidarity amongst the governed. This does not forward an alternative critical vision because it sees very little from which such an alternative might be constructed. The paradox of liberalism is one which is thus 
borne more or less directly out of its Eurocentrism, which takes Western agency and ideas as the only serious site of politics.

\section{Decolonising Critique: Three Intellectual Strategies}

This means that a radical critique of the liberal peace ultimately requires a more radical disruption of its Eurocentric epistemic underpinnings, and a repoliticisation of that sensibility of Western distinctiveness which is taken as an ontological 'given'. Mignolo and Quijano remind us that this kind of project - a de-colonial or decolonising project - must begin through a re-engagement with that which Eurocentric thinking suppresses or discounts; for us, this is that which is that which is exterior to the presumption of Western distinctiveness. This does not mean that which is untouched by colonial-modern forms of rule and knowledges - after all, the point is that there are hardly any such geographic spaces. It means that which locates or re-locates itself epistemically and methodologically at the boundaries of the colonial-modern, finding different political sites from which to think about the world, and constructing different problematiques for analysing it. Given the neoMarxist background of many of the thinkers under discussion, this intellectual reorientation is important to emphasise. Although sharing some of the concerns about the nature of intervention with neo- and post-Marxist critiques, the decolonising project seeks a deeper unsettling of how the political itself is framed. This section outlines concrete strategies for realising such a project, drawn from a range of critiques of Eurocentric thinking.

\section{Recovering Historical Political Presence}

As noted earlier, habits of methodological and analytic exclusion of target societies have also characterised some of the critiques of the liberal peace. Whilst there are clearly many differences between these and older colonial thinking, this iterated habit of exclusion is nonetheless a problematic one. It does seem to uphold the overall sensibility that nothing worth engaging with is going on outside the interventions themselves.

Relatedly, even when this exclusion is avoided, it is often the case that there is little if any historical grounding of the people targeted by interventions beyond the conflict which preceded the intervention (see Chandler 2000, Duffield 2007, Richmond and Franks 2009). This also compounds the erroneous impression - an impression sometimes formed by students reading the critical literature as well as countless practitioners - that the very ideas of peace and democracy are somehow 'new' imports of the peacebuilders to benighted post-conflict environments. 
If critical scholars are to displace this habit of analytic negation and the errors it produces, it must be in part through an extended appreciation of the historical political presence of societies targeted by interventions, and of forms of rule, power and resistance which existed in the territories. This is important both in terms of the peoples and spaces themselves, and in terms of their broader coeval connections to the constitution of global modernity. This appreciation was an important dimension of twentieth century anti-colonial thought, of which one key strand was the recovery of ongoing pre- and post-colonial 'presence' (see Cabral 1979).

On the one hand this recovery of presence can substantially contribute to repositioning the analytic gaze through fleshing out a knowledge of different ideas, values, issues and solidarities that constitute the pluralities of human political life. For example, Ayers' work on African political forms elaborates other historical modalities of authority and participation which sought to manage conflicts and inequalities between groups (Ayers 2006). This work challenges the Eurocentric sensibility that it is only Western or 'international' actors who have valuable political ideas and exercise meaningful political agency in the world.

On the other however, this appreciation of presence draws out the longstanding connections of mutual constitution between different societies which are so often buried by intervention discourses. This is crucial for undoing the Eurocentric presumption that 'modernity' itself emerged miraculously in one geographiccultural locale and is only now in the process of spreading across the world (see Bhambra 2010). This is important, because past encounters of colonisation and empire, which are for some not in the very distant past, come to have a much more direct influence and impact on contemporary interventions (Sabaratnam 2013).

This historical appreciation must also be coupled with an understanding of contemporary political presences, including an engagement with key political concerns, oppositions, motifs, discourses and patterns of action. These are central to being able to read intervention in a multi-sited way, and in terms of understanding its complex impacts on the political life of the target society. This awareness counteracts the tendency to read it as something which generally floats above or separate to other dynamics, re-grounding our conception of the political in public experience.

\section{Moving from (Alien) 'Culture' to Alienation}

As recognised earlier, of course, not all writers in the debate ignore the exteriority of interventions. Richmond (2010) has advocated the use of ethnographic methods, combined with principles of empathy and care as a means of engaging with 'everyday' relations and practices outside the vista of international 
interventions. These methods provide a clear counterweight to the habituated closures of some research, and opens up the possibility of engaging with the 'critical agency' or 'resistance' of those targeted by intervention. Yet, as earlier elaborated, it has a tendency to prioritise cultural difference, understood through traditions and customs, as the principal site of this politics.

As Balibar (1991) has argued, however, we must be wary of accounts and explanations that work on ontologies of 'cultural difference', which can functionally replicate ontologies of civilisation and race. Many anti-colonial thinkers were also suspicious of using 'culture' as a basis for political claim-making, recognising that more often than not it had become an instrument of political imprisonment and alienation (Fanon [1967] 2008), or a means of de-politicising colonial dominance (Said 1994). Indeed, within anthropology itself there have been strident critiques of the use of 'culture' as a framework which persistently re-inscribes the 'West'/'nonWest', 'self'/'Other' distinction (Abu-Lughod 1991).

The notion of 'colonial difference' forwarded by Mignolo and Quijano, emergent from these considerations, can be understood in this respect to re-politicise the distinctions and hierarchies made in assertions of 'cultural difference' as the constitutive ontology of the international (see also Neumann 1996). It does this through conceptualising the condition of 'coloniality' as a complex hierarchy of epistemic, political and material dynamics which have continuously fed into the sustenance of racialised imperial power over the last five centuries (Quijano 2000). This intellectual move can be understood as the equivalent of moving from understanding gender as a function of biology to a function of social powers which are not only constructed but maintain a complex, shifting hierarchy of masculinity over femininity.

The alternative to the culturalist framework is to re-politicise the field of action in which different peoples operate. One key strategy in anti-colonial thought was not to focus on the 'alien' (i.e. incomprehensible, inauthentic) character of colonial rule but its 'alienating' character - i.e. its displacements, violence, silencing, humiliations and dispossessions, which accrued to people as individuals and as a group. These included the epistemic violence done to symbols, social orders and knowledge. The point is that this becomes a positional, and thus political, story rather than a 'culturalist' one about 'difference'.

As a strategy, a positional critique requires a careful engagement with the experiences and critical political consciousness of those who are rendered as 'objects' of power, but who were never only silent and/or 'co-opted' through their involvement with particular structures. In research, in large part this means engaging with the ways in which different people politicise various aspects of their 
experiences, narrate the terms of their situations and critically interpret the world around them (Abu-Lughod 1991). Moreover, whilst it requires a reflexivity about the limits of one's own gaze (see Mac Ginty 2011: 4), it also requires a commitment to the possibility of substantive engagement with the particular politics of the situation (Ortner 1995).

This shift in emphasis I have sketched from 'alienness' to 'alienation', broadly understood, is an important one in the decolonising project because it refuses to organise the world into boxes primarily defined by 'culture', which tends to limit rather than deepen understanding. Rather, by emphasising the political content and context of human consciousness, meaning and agency, it re-positions the analytic gaze towards a fuller appreciation of the politics of the international. Indeed, there is an important radicality to the refusal of this ordering. This does not mean that 'culture' is epiphenomenal to consciousness, meaning and agency (Ortner 1995: 181182), but that 'cultures' are not the most important sub-divisions in international politics, and that 'individuals' themselves may never belong to them stably (Walley 1997).

Decolonising Political Economy: Politicising Entitlements, Dispossessions, Accumulations

Lastly, a fundamental means of re-politicising our understanding of phenomena is to try to understand their distributive impact. Important critiques of political economy have been made in the context of the liberal peace debate, particularly by Pugh and Duffield, who have drawn attention to the structural effects of neoliberalism in reducing state-provided social insurance (Pugh 2005; Duffield 2007), and the forms of elite corruption to which this contributes. Bringing considerations of political economy to the study of the liberal peace has also been an increasingly important trend in the wider scholarly community (see Pugh et al 2008), and there is a growing discussion about questions of labour economics (Cramer 2008), economic reconstruction policy (Mac Ginty 2011: 115-133), trade (Willett 2008), shadow economies (Pugh 2004) and the place of businesspeople in reconstruction (Woodward 2010).

These insightful and detailed engagements have however largely operated as analyses at arm's length from the peoples whose experiences are being studied. Even where these go beyond the broad structural level and into the details of particular economic spaces or systems, there is a tendency in the writing to skip over the interpretations given by people of their own situations, and to narrate these issues with the voice and gaze of the economist. In one particular article Divjak and Pugh (2008) do exceptionally go beyond this through engaging aspects of Bosnian public opinion around corruption. 
In keeping with the strategies of recovering historical political presence and politicising interpretations of intervention, it is also important to extend this awareness to discussions of the 'economic' or 'material' dimensions of intervention, which are co-constituted in important ways with the epistemic and political dimensions. This was strongly emphasised by anti-colonial materialists such as Cabral (1979). These political dimensions are as intrinsic to such seemingly mundane problems as differentials in aid salaries between internationals and nationals (McWha 2011) as they are to the 'bigger' problems of chronic and deep public indebtedness in post-conflict states.

To decolonise the way we think about the political economy of liberal peace interventions then means two things. First, it requires an engagement with how those targeted by interventions experience and interpret the material effects of that intervention. This means that accounts which base their analyses of intervention primarily on the structural tendencies of capitalism miss the multiple ways in which intervention itself constitutes a politics of distribution. Emerging work on the significance of aid fortresses in the political landscape, embodying the structure of aid entitlements, is thus to be welcomed (Duffield 2010). Second, it requires an analysis that politicises the various forms of entitlement, dispossession and accumulation that characterise the rationales for intervention and its distributive effects. This must avoid entangling itself in the language of 'development' - already widely recognised as a fundamentally colonial and de-politicising approach to poverty and economic policy (Escobar 1995; Ferguson 1990), and begin to challenge the historical terms on which this dysfunctional political economy is made thinkable.

\section{Conclusion}

Intellectual Eurocentrism is a hard habit to recognise and unpack. It is an even harder habit to kick, and I include myself as one who has struggled, not always successfully or completely, against the tendency to see the world on terms defined by the ontological distinctiveness of the West. It is deeply sedimented in many forms of common sense about the world, as well as in 'scholarly' and 'objective' IR theory (Hobson 2012). Indeed, disputes between different schools of thinking about the international can sometimes turn on which dimension of Eurocentrism they see as more important - the culturalist, the historical or the epistemic. As demonstrated above, these are all tendencies that can be read in present deliberations on the liberal peace, even where, as in all of these cases, the scholarship has been extremely rich, insightful and detailed.

For those who see themselves engaged in a post-imperial or anti-imperial critical project however, it is imperative that a serious effort is made to dismiss not 
just the old crude versions of Eurocentrism, but the new manifestations in which it quietly re-presents itself. As I have just suggested, this is best achieved through taking seriously questions of subjects' presence, positionality and the materiality of experience as the starting points for critical understandings of intervention. This is certainly not the easiest place for scholars to start with methodologically, either in terms of the practicalities of conducting substantive empirical research, or in terms of the personal and psychological disorientation that this kind of research may involve. Moreover, one may never be able to fully erase the sedimentations of Eurocentric knowledge, which in some ways goes to the very heart of the practice of professional scholarship.

But there is a distance to go before that last issue becomes a problem. Overall, the potential gains of this intellectual move against Eurocentrism have yet to be fully explored, particularly in International Relations where the historic quantity of research produced on this issue has been small in comparison to the writing that wilfully ignores it. Yet, it is clear that intellectual and methodological resources exist both within and beyond disciplinary boundaries to push this project much further, if there are people willing to take it on.

\section{Funding}

This research was supported by the Economic and Social Research Council, UK, by Studentship ES/F005431/1. 


\section{References}

Abu-Lughod, L. (1991) Writing Against Culture, in Richard Fox (ed.) Recapturing Anthropology: Working in the Present, Santa Fe, NM: School of American Research Press, 137-162

Ayers, A.J. (2006) Beyond the Imperial Narrative: African Political Historiography Revisited, in Jones, B. G. (ed) Decolonizing International Relations. Lanham, MD: Rowman \& Littlefield Publishers, 155-178.

Balibar, E. (1991) Is There a Neo-Racism? In Wallerstein, I., \& Balibar, E. Race, Nation, Class: Ambiguous Identities. (C. Turner, Trans.). London: Verso Books, 17-28.

Barkawi, T., \& Laffey, M. (2006). The postcolonial moment in security studies. Review of International Studies, 32(02), 329-352.

Barnett, M. \& Zürcher, C. (2009) The peacebuilder's contract: how external statebuilding reinforces weak statehood. In Paris, R., \& Sisk, T. D. The dilemmas of statebuilding: confronting the contradictions of postwar peace operations. London: Routledge, 23-52.

Begby, E. and J. P. Burgess (2009). Human Security and Liberal Peace. Public Reason 1(1), 91-104

Bhabha, H. K. (2004). The Location of Culture (2nd ed.). London: Routledge.

Bhambra, G. K. (2010) Rethinking Modernity: Postcolonialism and the Sociological Imagination, Basingstoke: Palgrave

Cabral, A. (1979) Unity and Struggle: Speeches and Writings of Amilcar Cabral. New York: Monthly Review Press.

Caplan, R. (2005). International governance of war-torn territories: rule and reconstruction. New York: Oxford University Press.

Chakrabarty, D. (2000). Provincializing Europe: postcolonial thought and historical difference. Princeton, N.J.: Princeton University Press.

Chandler, D. (2000). Bosnia: faking democracy after Dayton. London ; Sterling, Va.: Pluto Press. 
Chandler, D. (2006). Empire in denial: the politics of state-building. London ; Ann Arbor, MI: Pluto Press.

Chandler, D. (2009). Critiquing Liberal Cosmopolitanism? The Limits of the Biopolitical Approach. International Political Sociology, 3(1), 53-70.

Chandler, D. (2010a), International Statebuilding: The Rise of Post-liberal Governance, London: Routledge

Chandler, D. (2010b) 'The uncritical critique of liberal peace', Review of International Studies, 36(S1), 137-155

Chesterman, S. (2008) The Sovereignty Paradox: The Norms and Politics of International Statebuilding. American Journal of International Law 102(2), 405-410.

Cramer, C. (2008) From Waging War to Peace Work: Labour and Labour Markets, in Pugh, M., Cooper, N., \& Turner, M. (Eds.) Whose peace? Critical Perspectives on the Political Economy of Peacebuilding. Basingstoke: Palgrave, 123-140.

Cunliffe, P. (2012). Still the Spectre at the Feast: Comparisons between Peacekeeping and Imperialism in Peacekeeping Studies Today. International Peacekeeping, 19(4), 426-442.

Dillon, M. and Reid, J., (2000) Global governance, liberal peace and complex emergency, Alternatives: Global, Local, Political, 25(1), 117-145.

Divjak, B. and Pugh, M., (2008) The Political Economy of Corruption in Bosnia and Herzegovina, International Peacekeeping, 15(3), 373-386

Duffield, M. R. (2001). Global governance and the new wars : the merging of development and security. New York: Zed Books.

Duffield, M.R. (2005) Getting Savages to Fight Barbarians: Development, Security and the Colonial Present. Conflict, Security \& Development 5(2), 141-159.

Duffield, M. R. (2007). Development, security and unending war: governing the world of peoples. Cambridge: Polity.

Duffield, M.R. (2010) Risk-Management and the Fortified Aid Compound: Everyday Life in Post-Interventionary Society. Journal of Intervention and Statebuilding 4(4), 453474. 
Escobar, A. (1995) Encountering Development: The Making and Unmaking of the Third World. Princeton University Press.

Fanon F ([1967] 2008) Black Skin, White Masks, Revised edition, London: Pluto Press.

Ferguson, J. (1990) The Anti-politics Machine: Development," Depoliticization, and Bureaucratic Power in Lesotho. Cambridge: Cambridge University Press.

Götze, C., \& Guzina, D. (2008). Peacebuilding, Statebuilding, Nationbuilding-Turtles All the Way Down? Civil Wars, 10(4), 319-347.

Hindess, B. (2007). The Past Is Another Culture*. International Political Sociology, 1(4), 325-338.

Hobson, J. M. (2006). The Eastern origins of Western civilisation. Cambridge, UK; New York: Cambridge University Press.

Hobson, J. M. (2007) Is Critical Theory Always for the White West and for Western Imperialism? Beyond Westphilian Towards a Post-racist Critical IR. Review of International Studies 33 (S1): 91-116.

Hobson, J. M. (2012) The Eurocentric Conception of World Politics: Western International Theory, 1760-2010. Cambridge University Press.

Hutchings, K. (2008a) Making Sense of Masculinity and War. Men and Masculinities 10(4), 389-404.

Hutchings, K. (2008b). Time and world politics : thinking the present. Manchester ; New York: Manchester University Press.

Ignatieff, M. (2003) Empire Lite: Nation-building in Bosnia, Kosovo and Afghanistan. London: Vintage.

Jabri, V. (2007). Michel Foucault's Analytics of War: The Social, the International, and the Racial. International Political Sociology, 1(1), 67-81.

Jackson, P. T. (2010). The Conduct of Inquiry in International Relations: Philosophy of Science and Its Implications for the Study of World Politics. London: Routledge.

Jones, B. G. (2006). Decolonizing International Relations. Lanham, MD: Rowman \& Littlefield Publishers. 
Jones, L. (2011) 'Reviews: Critical interventions on Statebuilding', Journal of Intervention and Statebuilding, 5(2), 235-260.

Joseph, J. (2010). The limits of governmentality: Social theory and the international. European Journal of International Relations, 16(2), 223-246.

Krishna, S. (1993) The Importance of Being Ironic: a Postcolonial View on Critical International Relations Theory. Alternatives: Global, Local, Political 18, 385-417.

Mac Ginty, R. (2011). International Peacebuilding and Local Resistance: Hybrid Forms of Peace. Basingstoke: Palgrave.

McWha, I. (2011). The roles of, and relationships between, expatriates, volunteers, and local development workers. Development in Practice, 21(1), 29-40.

Mignolo, W. (2000). Local Histories/Global Designs: Coloniality, Subaltern Knowledges, and Border Thinking. Princeton University Press.

Mignolo, W. (2002). The Geopolitics of Knowledge and the Colonial Difference. The South Atlantic Quarterly, 101(1), 57-96.

Mitchell, A. (2011) Quality/control: International Peace Interventions and 'the Everyday'. Review of International Studies 37(4), 1623-1645.

Neumann, I. B. (1996) Self and Other in International Relations. European Journal of International Relations 2(2), 139-174.

Ortner, S. (1995) Resistance and the Problem of Ethnographic Refusal. Comparative Studies in Society and History 37(1), 173-193.

Paris, R. (2010) Saving Liberal Peacebuilding, Review of International Studies,36(2) 337365.

Pugh, M. (2004), 'Rubbing salt into war wounds: Shadow Economies and Peacebuilding in Bosnia and Kosovo', Problems of Post-Communism, 51(3), 53-60.

Pugh, M. (2005) 'The political economy of peacebuilding: a critical theory perspective', International Journal of Peace Studies, 10(2), 23-42.

Pugh, M (2008), 'Employment, Labour Rights and Social Resistance', in Pugh, M., Cooper, N., \& Turner, M. (Eds.). (2008). Whose peace? Critical Perspectives on the Political Economy of Peacebuilding. Basingstoke: Palgrave, 139-156. 
Pugh, M. (2009) 'Towards life welfare' in Newman, E., Paris, R., \& Richmond, O. P. (2009). New perspectives on liberal peacebuilding. Tokyo: United Nations University Press.

Pugh, M., Turner, M. and Cooper, N., (2008) 'Conclusion: The Political Economy of Peacebuilding - Whose Peace? Where Next?' in Pugh, M., Cooper, N., \& Turner, M. (Eds.) Whose peace? Critical Perspectives on the Political Economy of Peacebuilding. Basingstoke: Palgrave, 139-156

Quijano, A. (2000). Coloniality of Power and Eurocentrism in Latin America. International Sociology, 15(2), 215-232.

Quijano, A. (2007). Coloniality and Modernity/Rationality. Cultural Studies, 21(2-3), 168-178.

Richmond, O. P. (2005). The transformation of peace. Basingstoke: Palgrave Macmillan.

Richmond, O. P. (2006). The problem of peace: Understanding the 'Liberal Peace'. Conflict, Security \& Development, 6(3), 291-314.

Richmond, O. P. (2008). Welfare and the Civil Peace: Poverty with Rights? In Pugh, M., Cooper, N., \& Turner, M. (Eds.) Whose peace? Critical Perspectives on the Political Economy of Peacebuilding. Basingstoke: Palgrave, 289-303.

Richmond, O. P. (2009). A post-liberal peace: Eirenism and the everyday. Review of International Studies 35(03): 557-580

Richmond, O.P. (2010) 'Resistance and the post-liberal peace', Millennium: Journal of International Studies, 38:3, 665-692

Richmond, O.P. (2011) A Post-Liberal Peace: the local Infrapolitics of Peacebuilding, London: Routledge.

Richmond, O. P., \& Franks, J. (2009). Liberal Peace Transitions: Between Statebuilding and Peacebuilding. Edinburgh University Press.

Sabaratnam M, (2013). History Repeating? Colonial, socialist and liberal statebuilding in Mozambique', in Chandler D and Sisk T (eds) (2013) International Statebuilding: A Routledge Handbook, London: Routledge, 106-117.

Said, E. W. (1973/2003). Orientalism. London: Penguin. 
Said, E. W. (1994). Culture and imperialism. London: Vintage.

Shilliam, R. (ed.) (2010) International Relations and Non-Western Thought: Imperialism, Colonialism and Investigations of Global Modernity. London: Routledge.

Walker, R.B.J. (1993) Inside /Outside: International Relations as Political Theory, Cambridge: CUP.

Wallerstein, I. (1997). Eurocentrism and its avatars: The dilemmas of social science. New Left Review, NLR 226, 93-108.

Walley, C. J. (1997). Searching for" voices": Feminism, Anthropology, and the global debate over female genital operations. Cultural Anthropology, 12(3), 405-438.

Wæver, O. (1998). The Sociology of a Not So International Discipline: American and European Developments in International Relations. International Organization, 52(04), $687-727$.

Willett, S. (2008) Trading with Security: Trade Liberalisation and Conflict, in Pugh, M., Cooper, N., \& Turner, M. (Eds.) Whose peace? Critical Perspectives on the Political Economy of Peacebuilding. Basingstoke: Palgrave, 139-156.

Woodward, S. L. (2010). Soft Intervention and the Puzzling Neglect of Economic Actors. In Hoddie, M. and Harztell, C.A. (eds) Strengthening Peace in Post-Civil War States: Transforming Spoilers into Stakeholders, 189-218, Chicago: University of Chicago Press.

Zaum, D. (2007) The Sovereignty Paradox: the Norms and Politics of International Statebuilding. Oxford ; New York: Oxford University Press.

\footnotetext{
i There are two broad debates on the 'liberal peace' in the study of world politics. One looks at war and regime-type, and the other centres around the definitions given to peacebuilding by Duffield (2001) and Richmond (2005). This article focuses on the latter.

ii As pointed out by one of the reviewers of this piece, this literature has also largely emerged within the context of UK-based scholarship. I agree that this is sociologically interesting but cannot explore the reasons why here. Waever's (1998) reflections on the sociology of the discipline are however pertinent.
} 